\title{
GAMBARAN TINGKAT PENGETAHUAN TENAGA KERJA PT " $X$ " TENTANG UNDANG-UNDANG DAN PERATURAN KESEHATAN DAN KESELAMATAN KERJA
}

\author{
Andi Hendrawan $^{1)}$, Budi Sampurno ${ }^{2)}$, Kristian Cahyandi ${ }^{3)}$ \\ Dosen Akademi Maritim Nusantara Cilacap \\ andi_hendrawan@amn.ac.id ${ }^{1)}$
}

\begin{abstract}
The purpose of this study is to describe the level of knowledge of the workforce about legislation and regulations on occupational health and safety. Work safety has been a concern in government and business for a long time. Occupational safety factors are important because they are closely related to employee performance and in turn to company performance. The increasing availability of work safety facilities the less likely the occurrence of work accidents. This research is urvey with approach of cross sectional approach. sample are 40 people with total sampling technique, asked to fill questionnaires distributed by researcher then collected and analyze diskriptively. the results showed 10 respondent have a good level of knowledge, 25 respondent have sufficient knowledge level, and 5 respondent have a less knowledge level.
\end{abstract}

Keywords: Level of knowledge, law, health and safety

\section{PENDAHULUAN}

Keselamatan kerja telah menjadi perhatian di kalangan pemerintah dan bisnis sejak lama. Faktor keselamatan kerja menjadi penting karena sangat terkait dengan kinerja karyawan dan pada gilirannya pada kinerja perusahaan. Semakin tersedianya fasilitas keselamatan kerja semakin sedikit kemungkinan terjadinya kecelakaan kerja.

Kecelakaan kerja tidak saja menimbulkan korban jiwa maupun kerugian materi bagi pekerja dan pengusaha, tetapi juga dapat mengganggu proses produksi secara menyeluruh, merusak lingkungan yang pada akhirnya akan berdampak pada masyarakat luas.

Penyakit Akibat Kerja (PAK) dan Kecelakaan Kerja (KK) di kalangan tenaga kerja di Indonesia belum terekam dengan baik. Jika kita pelajari angka kecelakaan dan penyakit akibat kerja di beberapa negara maju (Hendrawan, 2018, 2019) (dari beberapa pengamatan) menunjukan kecenderungan peningkatan prevalensi. Sebagai faktor penyebab, sering terjadi karena kurangnya kesadaran pekerja dan kualitas serta keterampilan pekerja yang kurang memadai. Banyak pekerja yang meremehkan risiko kerja, sehingga tidak menggunakan alat-alat pengaman walaupun sudah tersedia. Dalam penjelasan undang-undang nomor 23 tahun 1992 tentang Kesehatan telah mengamanatkan antara lain, setiap tempat kerja harus melaksanakan upaya kesehatan kerja, agar tidak terjadi gangguan kesehatan pada pekerja, keluarga, masyarakat dan lingkungan disekitarnya.

Berdasarkan studi pendahluan di berberapa perusahaan menunjukan bahwa tingkat pengetahuan tenaga kerja masih ada yang kurang dengan rata-rata cukup. Penelitian ini bertujuan untuk meneliti tingkat pengetahuan tenaga kerja perihal undang-undang kesehatan dan keselamatan kerja. 


\section{Kesehataan dan Kesealamatan Kerja Dasar Hukum Undang - Undang Keselamatan Kerja}

1. Undang-Undang Dasar 1945, pasal 5, 20 dan 27

2. UU No. 1 Tahun 1970 Keselamatan dan kesehatan kerja

3. Undang Undang RI No.13 Tahun 2003 Tentang Ketenagakerjaan.

4. Selain itu ada beberapa Peraturan yang Berkaitan dengan $\mathrm{K} 3$, antara lain:

a. UU No. 1 tahun 1951 tentang Pernyataan Berlakunya UU Kerja Tahun 1948 No. 1, yang memuat aturan-aturan dasar tentang pekerjaan anak, orang muda dan wanita, waktu kerja, istirahat dan tempat kerja.

b. UU UAP (Stoon Ordonantie, Stdl. No.225 tahun 1930), yang mengatur keselamatan kerja secara umum dan bersifat nasional.

c. UU Timah Putih Kering, yang mengatur tentang larangan membuat, memasukkan, menyimpan atau menjual timah putih kering kecuali untuk keperluan ilmiah dan pengobatan atau dengan izin dari pemerintah.

d. UU Petasan, yang mengatur tentang petasan buatan yang diperuntukkan untuk kegembiraan/keramaian kecuali untuk keperluan pemerintah.

e. UU Rel Industri, yang mengatur tentang pemasangan, penggunaan jalan-jalan rel guna keperluan perusahaan pertanian, kehutanan, pertambangan, kerajinan dan perdagangan.

f. UU No. 3 Tahun 1969 tentang Persetujuan Konvensi ILO No. 120 mengenai Hygiene dalam Perniagaan dan Kantor-kantor.

g. UU No. 3 Tahun 1992 tentang Jaminan Sosial:

Kesemalatan dan Kesehatan Kerja ini juga disinggung secara singkat dalam Undang-Undang Nomor 13 Tahun 2003 tentang Ketenagakerjaan. UndangUndang Ketenagakerjaan tersebut menjelaskan bahwa Keselamatan dan Kesehatan Kerja merupakan bagian dari hak dari setiap pekerja atau buruh untuk memperoleh perlindungan.

Undang-Undang Ketenaga-kerjaan juga menjelaskan bahwa pemberian perlindungan keselamatan dan kesehatan kerja bagi pe-kerja atau buruh dilakukan dengan tujuan untuk mendukung mewujudkan produktivitas kerja yang optimal. Oleh karena itu, setiap perusahaan memiliki kewajiban untuk menerapkan sistem mana-jemen keselamatan dan kesehatan kerja yang terintegrasi dengan sistem manajemen perusahaan.

Kesehatan Kerja adalah bagian dari ilmu kesehatan yang bertujuan agar tenaga kerja memper-oleh keadaan kesehatan yang sempurna baik fisik maupun mental dan sosialnya sehingga memung-kinkan bekerja secara optimal. Tujuan dari adanya peraturan mengenai Kesehatan kerja adalah:

1. Meningkatkan dan memelihara derajat kesehatan tenaga kerja yang setinggitingginya baik fisik, mental dan sosial.

2. Mencegah dan melindungi tenaga kerja dari gangguan kesehatan yang disebabkan oleh kon-disi lingkungan kerja.

3. Menyesuaikan tenaga kerja dengan pekerjaan atau pekerjaan dengan tenaga kerja.

4. Meningkatkan produktivitas kerja Pengawasan Kesehatan Keselamatan Kerja ( K3 ) Sesuai dengan Undang - Undang Nomor 1 Tahun 1970 ayat 8 pengawasan $\mathrm{K} 3$ meliputi

1. Pengurus diwajibkan memeriksakan kesehatan badan, kondisi mental dan kemampuan fisik dari tenaga kerja yang akan diterimanya maupun akan dipindahkan sesuai dengan sifat-sifat pekerjaan yang diberikan padanya. 
2. Pengurus diwajibkan memeriksa semua tenaga kerja yang berada di bawah pimpinannya

3. secara berkala pada Dokter yang ditunjuk oleh Pengusaha dan dibenarkan oleh Direktur. Normanorma mengenai pengujian kesehatan ditetapkan dengan peraturan perundangan.

\section{PENGETAHUAN}

\section{Pengertian Pengetahuan}

Menurut (Notoadjmojo, 2010) dan (Puspitasari, 2014; Sariningrum, 2009; Soraya, 2013) Pengetahuan adalah merupakan hasil " tahu" dan ini terjadi setelah orang melakukan penginderaan terhadap suatu objek tertentu. Penginderaan terjadi melalui panca indra manusia, yakni indra penglihatan, pendengaran, penciuman, rasa dan raba. Sebagian besar pengetahuan manusia diperoleh melalui mata dan telinga.

Pengetahuan atau kognitif merupakan dominan yang sangat penting untuk terbentuknya tindakan seseorang / overt behavior, karena dari pengalaman dan penelitian ternyata perilaku yang didasari oleh pengetahuan akan lebih langgeng dari pada perilaku yang tidak didasari oleh pengetahuan.

\section{Tingkatan Pengetahuan}

Penelitian Rogers (Notoatmodjo, 2010). (Chandra, 2009; Sani, 2011; SYARFA, 2015) mengungkapkan bahwa sebelum orang mengadopsi perilaku baru (berperilaku baru),di dalam diri orang tersebut terjadi proses yang berurutan, yakni:

a. Awareness/kesadaran, dimana orang tersebut menyadari dalam arti mengetahui terlebih dahulu terhadap stimulasi/objek.

b. Interest/merasa tertarik terhadap stimulus atau objek tersebut. Di sini sikap subjek mulai timbul.

c. Evaluation/menimbang-nimbang terhadap baik dan tidaknya stimulus tersebut bagi dirinya. Hal ini berarti sikap responden sudah lebih baik lagi.

d. Trial, dimana subjek mulai mencoba melakukan sesuatu sesuai dengan apa yang dikehendaki oleh stimulus.

e. Adaption, dimana subjek telah berperilaku baru sesuai dengan pengetahuan, kesadaran dan sikapnya terhadap stimulus.

Penerimaan perilaku baru atau adopsi perilaku proses yang didasarioleh pengetahuan, kesdaran dan sikap yang positif, akan bersifat langgeng atau longlasting. Namun perilaku yang tidak didasari oleh pengetahuan dan kesadaran akan tidak berlangsung lama. (Artiningsih, 2011; Chandra, 2009; Notoadjmojo, 2010).

Menurut (Notoadjmojo, 2010) pengetahuan atau kognitif merupakan domain yang sangat penting untuk terbentuknya tindakan seseorang (ovent behavior). Dari pengalaman dan penelitian ternyata perilaku yang didasari oleh penggetahuan. Pengetahuan yang cukup didalam domain kognitif mempunyai 6 tingkat yaitu :

\section{a. Tahu/Know}

Tahu diartikan sebagai pengingat suatu meteri yang telah dipelajari sebelumnya.Termasuk ke dalam tingkat ini adalah mengingat kembali/recall terhadap sutau yang spesifik dari seluruh bahan yang dipelajari atau rangsangan yang telah diterima. Oleh sebab itu, tahu ini adalah merupakan tingkatan pengetahuan yang paling rendah.

Kata kerja untuk mengukur bahwa orang tahu tentang apa yang dipelajari antaralain: menyebutkan, menguraikan, mendefinisikan, menyatakan dan sebagianya. Contoh : dapat menyebutkan tanda-tanda kekurangan kalori dan protein pada anak balita.

\section{b. Memahami/Komprehension}

Memahami diartikan sebagai suatukemampuan menjelaskan secara 
benar objek yang diketahui dan dapat menginterpretasi materi tersebut secara benar.Orang yang elah paham terhadap objek atau materi harus dapat menjelaskan, menyebutkan contoh, menyimpulkan, meramalkan, dan sebagainya terhadap objek yang dipelajari. Misalnya dapat menjelaskan mengapa harus makan makanan yang bergizi.

\section{c. Aplikasi/Application}

Menggunakan materi yang telah dapat pada situasi atau kondisi yang sebenarnya. Aplikasi disini dapat diartikan aplikasi atau penggunaan hukum-hukum, rumus, metode, prinsip dan sebagainya dalam konteks atau situasi yang lain. Misalnya dapat menggunakan rumus statistik dalam perhitungan-perhitungan hasil penelitian, dapat menggunakan prinsip-prinsip siklus pemecahan masalah/problem solving cycle di dalam pemecahan masalah dari kasus yang diberikan.

\section{d. Analisis/Analysis}

Analisis adalah suatu kemampuan untuk menjabarkan materi atau suatu objek ke dalam komponen-komponen, tetapi masih ada kaitannya satu sama lain. Kemampuan analisaini dapat dilihat dari penggnaan kata-kata kerja: dapat menggambarkan atau membuat bagan, membedakan, memisahkan, mengelompokkan dan sebagainya.

\section{e. Sintesis/Synthesis}

Sintesis menuju kepada suatu kemampuan untuk meletakkan atau menghubungkan bagian-bagian di dalam suatu bentuk keseluruhanyang baru. Dengan kata lain sintesis itu suatu kemampuan untuk menyusun formulasi baru dari informasiinformasi yang ada misalnya : dapat menyusun, dapat merencanakan, dapat meringkaskan, dapat menyesuaikan, dan sebagainya terhadap suatu teori atau rumusanrumusan yang telah ada.

\section{f. Evaluasi/Evaluation}

Evaluasi ini berkaitan dengan kemampuan unntuk melakukan justifikasi atau penilaian terhadap suatu materi atau objek. Penilaianpenilaian itu berdasarkan suatu kriteria yang ditentukan sendiri, atau menggunakan kriteria-kriteria yang telah ada.

Pengukuran pengetahuan dapat dilakukan dengan wawancarca atau angket yang menanyakan tentang isi materi yang ingin diukur dari subjek penelitian atau responden. Kedalaman pengetahuan yang ingin kita ketahui atau kita ukur dapat kitasesuaikan dengan tingkah-tingkah tersebut di atas (Notoatmodjo, 2003).

\section{Cara Memperoleh Pengetahuan}

Berbagai macam cara yang telah digunakan untuk memperoleh kebenaran pengetahuan sepanjang sejarah, dapat dikelompokkan menjadi dua, yakni cara tradisional atau non ilmiah, yaitu tanpa melalui penelitian ilmiah dan cara modern atau cara ilmiah, yakni melalui proses penelitian:

\section{a. Cara Memperoleh Kebenaran Non ilmiah}

Cara kuno atau tradisional ini dipakai orang untuk memperoleh kebenaran pengetahuan sebelum ditemukannya metode ilmiah atau metode penemuan secara sistematik dan logis adalah dengan cara non ilmiah, tanpa melalui penelitian. Cara-cara penemuan pengetahuan pada periode ini antara lain meliputi:

\section{1) Cara coba salah (trial and eror) \\ Cara memperoleh}

kebenaran non ilmiah, yang pernah digunakan oleh manusia dalam memperoleh pengetahuan adalah melalui cara coba-coba atau dengan kata yang lebih dikenal "trial and eror". Cara ini telah 
dipakai orang sebelum kebudayaan, bahkan mungkin sebelum adanya peradaban. Cara coba salah ini dilakukan dengan menggunakan beberapa kemungkinan dalam memecahkan masalah, dan apabila kemungkinan tersebut tidak berhasil, dicoba kemungkinan yang lain. Apabila kemungkinan kedua ini gagal pula, maka di coba lagi dengan kemungkinan ketiga, dan apabila kemungkinan ketiga gagal dicoba kemungkinan keempat dan seterusnya, sampai masalah tersebut dapat terpecahkan. Itulah sebabnya makan cara ini disebut metode trial (coba) and error (gagal atau salah) atau metode coba salah (coba-coba).

Metode ini telah digunakan orang dalam waktu yang cukup lama untuk memecahkan berbagai masalah. Bahkan sampai sekarang pun metode ini masih sering digunakan, terutama oleh mereka yang belum atau tidak mengetahui suatu cara tertentu yang tepat dalam memecahkan masalah yang dihadapi. Metode ini telah banyak jasanya, terutama dalam meletakkan dasar-dasar menemukan teori-teori dalam berbagai cabang ilmu pengetahuan. Hal ini juga merupakan pencerminan dari upaya memperoleh pengetahuan, walaupun pada taraf yang masih primitif. Disamping itu, pengalaman yang diperoleh melalui penggunaan metode ini banyak membantu perkembangan berfikir dan kebudayaan manusia kearah yang lebih sempurna.

\section{2) Secara kebetulan}

Penemuan kebenaran secara kebetulan terjadi karena tidak disengaja oleh orang yang bersangkutan.

3) Cara kekuasaan atau otoritas

Kehidupan manusia seharihari, banyak sekali kebiasaankebiasaan dalam tradisi-tradisi yang dilakukan tersebut baik atau tidak. Kebiasaan-kebiasaan ini biasanya diwariskan turuntemurun dari generasi ke generasi berikutnya. Kebiasaan seperti ini bukan hanya terjadi pada masyarakat tradisioal saja, melainkan juga terjadi pada masyarakat modern.

Sumber pengetahuan cara ini dapat berupa pemimpinpemimpin masyarakat baik formal atau informal, ahli agama, pemegang pemerintah, dan berbagai prinsip orang lain yang menerima mempunyai otoritas, tanpa menguji terlebih dahulu atau membuktikan kebenarannya baik berdasarkan fakta empiris maupun penalaran sendiri.

4) Berdasarkan pengalaman pribadi

Pengalaman pribadi dapat digunakan sebagai upaya memperoleh pengetahuan dengan cara mengulang kembali pengalaman yang pernah diperoleh dalam memecahkan permasalahan yang dihadapi masa lalu. Apabila dengan cara yang digunakan tersebut orang dapat memecahkan masalah yang dihadapi, maka untuk memecahkan masalah yang lain yang sama orang dapat pula menggunakan cara tersebut.

Tetapi bila gagal
menggunakan cara cara
tersebut, tidak akan mengulangi
cara itu, dan berusaha untuk


mencari cara yang lain,
sehingga
memecahkannya.

5) Cara akal sehat (common Sense)

Akal sehat atau common sense kadang-kadang dapat menemukan teori atau kebenaran. Sebelum ilmu pendidikan ini berkembang, para orangtua zaman dahulu agar anak mau menuruti nasihat orangtuanya atau agar anak disiplin menggunakan cara hukuman fisik bila ananknya berbuat salah. Ternyata cara menghukum anak seperti ini sampai sekarang berkembang menjadi teori atau kebenaran, bahwa hukuman adalah merupakan metode (meskipun bukan yang paling baik) bagi pendidikan anak.

6) Kebenaran melalui wahyu

Ajaran dan norma agama adalah suatu kebenaran yang diwahyukan dari Tuhan melalui para Nabi. Kebenaran ini harus diterima dan diyakini oleh pengikut-pengikut agama yang bersangkutan, terlepas dari apakah kebenaran tersebut rasional atau tidak. Sebab kebenaran ini diterima oleh para nabiadalah sebagai wahyu dan bukan karena ahsil usaha penalaran atau penyelidikan manusia.

\section{7) Kebenaran secara intuitif}

Kebenaran secara intuitif diperoleh manusia secara cepat sekali melalui proses di luar kesadaran dan tanpa melalui proses penalaran atau berfikir. Kebenaran yang diperoleh melalui intuitif sukar dipercaya karena kebenaran ini tidak menggunakan cara-cara yang rasional dan sistematis. Kebenaran ini diperoleh seseorang hanya berdasarkan intuisi atau suara hati atau bisikan hati saja.

8) Melalui jalan pikiran

Sejalan dengan perkembangan kebudayaan umat manusia, cara berfikir manusia pun ikut berkembang. Dari sini manusia telah mampu menggunakan penalaran dalam memperoleh kebenaran pengetahuannya. Dengan kata lain, dalam memperoleh kebenaran pengetahuan manusia telah menggunakan jalan pikirnya, baik melalui induksi maupun deduksi.

Induksi dan deduksi pada dasarnya merupakan cara melahirkan pemikiran secara tidak langsung melalui pernyataan-pernyataan yang dikemukakan, kemudian dicari hubungannya sehingga dapat dibuat suatu kesimpulan. Apabila proses pembuatan kesimpulan itu melalui pernyataan-pernyataan umum kepada yang khusus.

9) Induksi

Sebagaimana telah disebutkan sebelumnya, bahwa induksi adalah proses penarikan kesimpulan yang dimulai dari pernyataan-pernyataan khusus ke pernyataan yang bersifat umum. Hal ini berarti dalam berfikir induksi pembuatan kesimpulan tersebut berdasarkan pengalamanpengalaman empiris yang ditangkap oleh indra. Kemudian pengalaman empiris yang ditangkap oleh indra. Kemudian disimpulkan kedalam suatu konsep yang memungkinkan seseorang untuk memahami suatu gejala. Karena proses berfikir induksi itu beranjak dari hasil pengamatan indra 
atau hal-hal yang nyata, maka dapat dikatakan bahwa induksi beranjak dari hal-hal yang kongkret kepada hal-hal yang abstrak.

Proses berfikir induksi dikelompokkan menjadi dua, yakni induksi sempurna dan induksi tidak sempurna.. induksi tidak sempurna terjadi apabila kesimpulan diperoleh dari penjumlahan dari kesimpulan khusus, sedangkan induksi tak sempurna terjadi apabila kesimpulan tersebut diperoleh dari lompatan, dari pernyataan-pernyataan khusus. Hal ini berarti bahwa dasar dari kesimpulan tersebut bukan penjumlahan dari tiap-tiap subjek yang diamati, melainkan hanya beberapa subjek saja sebagai sample.

\section{0) Deduksi}

Deduksi adalah pembuatan kesimpulan dari pernyataanpernyataan umum ke khusus. Aristoteles (384-322 SM) mengembangkan cara berfikir deduksi ini ke dalam suatu cara yang disebut "silogisme". Silogisme ini merupakan suatu bentuk deduksi yang memungkinkan seseorang untuk mencapai kesimpulan yang lebih baik. Didalam proses berfikir deduksi berlaku bahwa sesuatu yang dianggap benar secara umum pada kelas tertentu.

Berlaku juga kebenarannya pada semua peristiwa yang terjadi pada setiap yang termasuk dalam kelas itu. Disini terlihat proses berfikir berdasarkan pada pengetahuan yang umum mencapai pengetahuan yang khusus. Silogisme sebagai bentuk berfikir deduksi yang teratur terdiri dari tiga pernyataan atau proporsisi, yaitu : pernyataan pertama disebut premis mayor, yang berisi pernyataan yg bersifat umum. Pernyataan kedua yang bersifat lebih khusus daripada pernyataan ketiga yang merupakan kesimpulannya, disebut konklusi atau konsekuen.Silogisme terjadi dua macam yaitu silogisme kategoris dan silogisme hipotesis.(Notoatmodjo,2010)

b. Cara ilmiah dalam Memperoleh Pengetahuan

Cara baru atau modern dalam memperoleh pengetahuan pada dewasa ini lebih sistematis, logis dan ilmiah.(Notoadjmojo, 2010; Octavia, 2009).

\section{Faktor-faktor yang Mempengaruhi} Pengetahuan

\section{a. Faktor internal}

\section{1) Pendidikan}

Pendidikan

berarti

bimbingan yang diberikan seseorang terhadap perkembangan orang lain menuju kearah cita-cita tertentu yang menentukan manusia untuk berbuat dan mengisi kehidupan untuk mencapai keselamatan dan kebahagiaan.

$$
\text { Pendidikan diperlukan }
$$
untuk mendapat informasi misalnya hal-hal yang menunjang kesehatn sehingga dapat meningkatkan kualitas hidup. Menurut YB Mantra yang dikuti Notoadmojo (2010), pendidikan dapat mempengaruhi seseorang termasuk juga perilaku seseorang akan pola hidup terutama dalam memotivasi untuk sikap berperan serta dalam pembangunan pada umumnya makin tinggi 
pendidikan seseorang makin mudah menerima informasi.

2) Pekerjaan

Menurut Thomas yang dikutip oleh Nursalam (2003), pekerjaan adalah keburukan yang harus dilakukan terutama untuk menunjang kehidupannya dan kehidupan keluarga. Pekerjaan bukanlah sumber kesenangan, tetapi lebih banyak merupakan cara mencari nafkah yang membosankan, berulang dan banyak tantangan. Sedangkan bekerja umumnya merupakan kegiatan yang menyita waktu. Bekerja bagi ibu-ibu akan mempunyai pengaruh terhadap kehidupan keluarga.

3) Umur

Menurut Elisabeth BH yang dikutip Nursalam (2003), usia adalah umur individu yang terhitung mulai saat dilahrkan sampai berulang tahun. Sedangkan menurut Huclok (1998) semakin cukup umur, tingkat kematanngan dan kekuatan seseorang akan lebih matang dalam berfikir dan bekerja. Dari segi kepercayaan masyarakat seseorang yang lebih dewasa dipercaya dari orang yang belum tinggi kedewasaannya. Hal ini akan sebagai dari pengalaman dan kematangan jiwa.

\section{b. Faktor Eksternal}

\section{1) Faktor lingkungan}

Menurut Ann. Mariner yang dikutip Nursalam lingkungan merupakan seluruh kondisi yang ada disekitar manusia dan pengaruhnya yang dapat mempengaruhi perkembangan dan perilaku orang atau kelompok.

\section{2) Sosial budaya}

Sistem sosial budaya yang ada pada masyarakat dapat mempengaruhi dari sikap dalam menerima informasi. (Wawan dan Dewi,2010)

\section{Pengukuran Tingkat Pengetahuan}

Pengukuran pengetahuan dapat dilakukan dengan wawancara atau angket yang menayakan tentang isi materi yang ingin diukur dari subjek penelitian atau responden. Kedalaman pengetahuan yang ingin diketahuiatau diukur dapat disesuaikan dengan tingkat diatas. (Arikunto, 2010; Notoadjmojo, 2010) pengetahuan seseorang dapat diketahui dan di interprestasikan dengan skala yang bersifat kualitatif, yaitu :

1. Baik (Hasil prosentase 76-100\%)

2. Cukup (Hasil prosentase $56-75 \%$ )

3. Kurang (Hasil prosentase $<56 \%$ )

\section{METODE PENELITIAN}

\section{A. Kerangka Konsep}

Variabel Kriteria

\begin{tabular}{|lr|}
\hline Tingkat & Pengetahuan \\
Tenaga Kerja PT 'X' \\
Tentang r Undang- \\
Undang Dan Peraturan \\
Kesehatan r Dan \\
Keselamatan Kerja
\end{tabular}$\quad \longrightarrow$\begin{tabular}{c} 
Baik \\
Cukup \\
Kurang \\
\hline
\end{tabular}

Gambar 1. Kerangka konsep.

\section{B. Variabel Penelitian}

Variabel mengandung pengertian ukuran atau ciri yang dimiliki oleh anggota-anggota suatu kelompok yang berbeda dengan yang dimiliki oleh kelompok lain (Notoatmodjo, 2010). Variabel yang digunakan adalah dua variabel yaitu :

Variabel Bebas (Independent)

Variabel bebas dari penelitian ini adalah tingkat penegtahuan tenaga kerja PT'X' tentang undang-undang dan peraturan kesehatan dan keselamatan kerja. 


\section{Definisi Operasional (DO) Variabel}

Definisi operasional adalah uraian tentang batasan variabel yang dimaksud, atau tentang apa yang diukur oleh variabel yang bersangkutan. Definisi operasional juga bermanfaat untuk mengarahkan kepada pengukuran atau pengamatan terhadap variabel-variabel yang bersangkutan serta pengembangan instrumen (alat ukur).

Definisi operasional dalam penelitian ini adalah sebagai berikut: Tabel 1. Definisi Operasional

\begin{tabular}{|c|c|c|c|}
\hline Variabel & $\begin{array}{c}\text { Definisi } \\
\text { Operasi- } \\
\text { onal }\end{array}$ & $\begin{array}{c}\text { Para- } \\
\text { meter dan } \\
\text { Kategori }\end{array}$ & $\begin{array}{c}\text { Alat } \\
\text { Ukur } \\
\text { dan } \\
\text { Skala }\end{array}$ \\
\hline $\begin{array}{l}\text { Tingkat } \\
\text { pengetah } \\
\text { uan } \\
\text { tenaga } \\
\text { kerja } \\
\text { PT' "X"t } \\
\text { entang } \\
\text { undang- } \\
\text { undang } \\
\text { dan } \\
\text { peraturan } \\
\text { kesehata } \\
\text { n dan ke- } \\
\text { selamat- } \\
\text { an kerja }\end{array}$ & $\begin{array}{l}\text { Pengetah } \\
\text { uan dan } \\
\text { pemaha } \\
\text { man } \\
\text { tenaga } \\
\text { kerja PT } \\
\text { "X" } \\
\text { tentang } \\
\text { undang- } \\
\text { undang } \\
\text { dan } \\
\text { peraturan } \\
\text { kesehata } \\
\text { n dan ke- } \\
\text { selamat- } \\
\text { an kerja. }\end{array}$ & $\begin{array}{ll}\text { a. Baik : } & \text { : } \\
76 \%- \\
100 \% \\
\text { b. Cukup: } \\
\text { 56\%- } \\
75 \% \\
\text { c. Kurang } \\
:<56 \%\end{array}$ & $\begin{array}{l}\text { Kuesi } \\
\text { oner } \\
\text { Ordin } \\
\text { al }\end{array}$ \\
\hline
\end{tabular}

\section{Rancangan Penelitian}

\section{Jenis / Desain Penelitian}

Jenis penelitian yang digunakan dalam penelitian ini menggunakan metode penelitian diskriptif yaitu penelitian mencoba menggali bagaimana dan mengapa fenomena kesehatan itu terjadi. Pendekatan yang digunakan sdalam penelitian ini adalah cross sectional. Cross sectional adalah suatu penelitian untuk mempelajari dinamika korelasi antara faktorfaktor resiko dengan efek, dengan cara pendekatan, observasi atau pengumpulan data sekaligus pada suatu saat (Notoatmodjo, 2010).
2. Populasi, Sampel, dan Teknik Sampling

Populasi adalah keseluruhan objek penelitian atau objek yang diteliti. Penelitian ini populasinya adalah seluruh tenaga kerja di PT $\mathrm{X}$ Sampel adalah objek yang diteliti dan dianggap mewakili seluruh populasi (Notoadjmojo, 2010)Teknik pengambilan yang digunakan dalam penelitian ini adalah total sampling. Total sampling adalah pengambilan sampel diambil dari seluruh anggota populasi(Arikunto, 2006). Besarnya sampel yang digunakan dalam penelitian ini adalah 40 orang.

\section{Teknik Pengumpulan Data}

\section{a. Data Primer}

Diperoleh dengan menggunakan kuesioner. Kuesioner adalah sejumlah pertanyaan tertulis yang digunakan untuk memperoleh informasi dari responden dalam arti laporan tentang pribadinya, atau hal-hal yang ia ketahui (Arikunto, 2010; h.194). Pengumpulan data dilakukan dengan metode pengisian kuesioner oleh responden yang dilakukan secara langsung oleh peneliti terhadap sampel penelitian. Data primer penelitian ini diambil dari hasil jawaban responden dalam kuesioner yang disebarkan.

\section{Instrumen Penelitian}

Alat ukur yang digunakan dalam penelitian ini adalah kuesioner. Kuesioner terdiri yaitu tentang tingkat pengetahuan tenaga kerja $\mathrm{PT}^{\prime} \mathrm{X}^{\prime}$ tentang undangundang dan peraturan kesehatan dan keselamatan kerja variabel bebas Kuesioner sebelum diberikan kepada responden, dilakukan uji validitas dan reliabilitas (Notoatmodjo, 2010). 


\begin{abstract}
Bentuk kuisioner yang digunakan adalah bentuk pertanyaan tertutup (Closed ended) yang berjumlah 20 pertanyaan. Bentuk pertanyaan ini mempunyai keuntungan mudah mengarahkan jawaban responden, dan juga mudah diolah (tabulasi). Dalam pertanyaan ini responden hanya memberikan jawaban atau dengan memberikan tanda-tanda tertentu seperti tanda check $(\sqrt{ })$. Dengan demikian kuisioner ini sering juga disebut "daftar pertanyaan" (formulir) (Arikunto, 2010).
\end{abstract}

\section{a. Uji Validitas}

Validitas adalah suatu indeks yang menunjukkan alat ukur itu benar-benar mengukur apa yang diukur. Untuk mengetahui apakah kuesioner yang kita susun tersebut mampu mengukur apa yang hendak kita ukur, maka perlu diuji dengan uji korelasi antara skor (nilai) tiap-tiap item (pertanyaan) dengSan skor total kuesioner tersebut. Bila semua pertanyaan itu mempunyai korelasi yang bermakna (construct validity) berarti semua item (pertanyaan) yang ada didalam kuesioner itu mengukur konsep yang kita ukur (Notoatmodjo, 2010;).

$\mathrm{r}_{\mathrm{xy}}=\frac{N\left(\sum x y\right)-\left(\sum x\right)\left(\sum y\right)}{\sqrt{\left.\left[N \sum x^{2}-\left(\sum x\right)^{2}\right] N \sum y^{2}-\left(\sum y\right)^{2}\right]}}$

Keterangan :

$\mathrm{r}_{\mathrm{xy}}$ : Korelasi antara variabel $\mathrm{x}$ dan $\mathrm{y}$

$\mathrm{N}$ : Jumlah responden

$\mathrm{x}$ : Skor pertanyaan

$\mathrm{y}:$ Skor total

Jika hasil perhitungan ternyata $r_{\text {hitung }}>r_{\text {tabel }}$, maka butir instrumen dianggap valid, sebaliknya jika $r_{\text {hitung }}<r_{\text {tabel }}$, maka dianggap tidak valid (invalid), instrumen tidak dapat digunakan dalam penelitian.

\section{b. Uji Reliabilitas}

Reliabilitas adalah indek yang menunjukkan sejauh mana suatu alat pengukuran dapat dipercaya atau dapat diandalkan. Perhitungan reliabilitas harus dilakukan hanya pada pertanyaanpertanyaan yang sudah memiliki validitas (Notoatmodjo, 2010). Pengujian reliabilitas dengan pendekatan internal consistency, dilakukan dengan cara mencobakan instrumen sekali saja. Pengujian reliabilitas dengan pendekatan konsistensi internal, dengan alasan prosedurnya hanya memerlukan satu kali tes pada sekelompok subyek. Kemudian hasil yang diperoleh dianalisis dengan rumus Alpha Cronbach sebagai berikut :

$r_{11}=\left(\frac{k}{(k-1)}\right)\left(1-\frac{\sum \sigma_{b}^{2}}{\sigma_{t}^{2}}\right)$

Keterangan :

$\mathrm{r}_{11} \quad$ : reliabilitas instrumen

$\mathrm{k}$ : banyaknya butir pertanyaan

atau banyaknya soal

$\sum \sigma_{b}{ }^{2} \quad$ : jumlah varians butir

$\sigma_{t}^{2} \quad$ : varians total

Jika hasil perhitungan ternyata $r \geq$ 0,6, maka butir instrumen dianggap reliabel, sebaliknya jika $r<0,6$, maka dianggap tidak reliabel.

\section{Pengolahan Data}

1) Editing

Editing bertujuan untuk mengoreksi data yang meliputi kelengkapan pengisian atau jawaban yang tidka jelas. Editing dilaksanakan pada saat pengambilan data agar jika terjadi kesalahan atau kekurangan dapat diperbaiki / dilengkapi.

Setelah kuesioner dilengkapi oleh responden, kemudian dilakukan koreksi terhadap 
kuesioner dari masing-masing responden, sehingga jika ada kesalahan dapat segera diperbaiki.

2) Coding

Coding yakni mengubah data berbentuk kalimat atau huruf menjadi data angka atau bilangan (Notoatmodjo, 2010). Coding dilakukan untuk mempermudah dalam proses tabulasi dan analisa data selanjutnya. Coding dilakukan dengan cara :

Tingkat Pengetahuan

(1) Baik (76\% - 100\%) diberi kode 1

(2) Cukup $(60 \%-75 \%)$ diberi kode 2

(3) Kurang $(<60 \%)$ diberi kode 3

3) Scoring

Memberi nilai / skor pada masing-masing item yang perlu diberi skor. Memberikan nilai / skor pada masing-masing kuesioner dengan mengakumulasikan seluruh sekor item tiap pertanyaan dalam kuesioner yang telah diberi kode (coding) berdasarkan kriteria nilai yang telah dibuat. Penilaian yang dilakukan dengan memberikan poin pada setiap jawaban data yaitu kategori tingkat pengetahuan ibu baik atau tidak bila skor nilai baik $76 \%-100 \%$, cukup $60 \%-75 \%$, kurang $<60 \%$.

4) Entry Data

Entry data yakni jawabanjawaban dari masing-masing responden yang dalam bentuk kode (angka atau huruf) dimasukkan ke dalam program atau software computer. Salah satu program yang digunakan adalah paket program SPSS for Window (Notoatmodjo, 2010).

6. Analisis Data

1) Analisa Univariat

Analisa univariat yaitu menjelaskan atau mendeskripsikan karakteristik setiap variabel penelitian. Analisis ini dilakukan terhadap variabel hasil penelitian. Pada umumnya dalam analisis ini hanya menghasilkan distribusi frekuensi dan persentase dari tiap variabel (Notoatmodjo, 2010; h.182). Menurut Budiarto (2001; h.37) persentase dibuat dengan rumus sebagai berikut :

$$
p=\frac{f}{n} x 100 \%
$$

Keterangan :

$\mathrm{p}$ : presentase

f : hasil obyek yang diteliti

n : jumlah seluruh obyek

Data univariate yang akan dianalisa adalah tingkat pengetahuan tentang tenaga kerja $\mathrm{PT}^{\prime} \mathrm{X}^{\prime}$ tentang undang-undang dan peraturan kesehatan dan keselamatan kerja.

HASIL DAN PEMBAHASAN

Tabel 2.Gambaran tingkat pengetahuan

\begin{tabular}{ccc}
\hline $\begin{array}{c}\text { Tingkat } \\
\text { Pengetahuan }\end{array}$ & F & $\%$ \\
\hline Baik & 10 & 25 \\
Cukup & 25 & 52,5 \\
Kurang & 5 & 12,5 \\
\hline Jumlah & 40 & 100 \\
\hline
\end{tabular}

Berdasarkan tabel 2 diperlihatkan bahwa paling banyak pada kategori cukup yaitu 25 orang atau 52,5\% dan paling sedikit pada kategori kurang yaitu 5 orang atau 12,5. Pengetauan yang baik bisa disebabkan karena pendidikan tinggi. Pendiidkan yang tinggi memungkinkan sesorang memiliki pengetahuan yang lebih dari yang lain, Notoatmojo (2010) pendidikan berpengaruh terhadap tingkat pengetahuan sesorang, semakin orang berpendidikan maka tingkat pengetahuan makin tinggi.

Pengetahuan yang cukup tentang Undang-undang dan peraturan tenatang kesehatan dan keselamatan kerja, hal ini dikarena sudah ada program pelatihan tentang Dasar K3 (Kesehatan dan Keselamatan Kerja), sebelum menjadi pegawai, diadakan program pelaihan pegawai baru yang didalamnyasalahsatu materinya adalah UU dan peraturan 
tentang K3. PT X telahmelkasanakan hal tersebut sehingga pegawai yang belum cukup pengethuan tinggal 3 orang atau $12,5 \%$.

Pengetahuan pegewai yang masih kurang berdasarkan wawancara dikarena memang penfifikn masih rendah dan usia telah cukup lanjut menjelang pension sehingga sudah tidak lagi berkonsentrasi terhadap pekerjaan, (Hendrawan, 2018; Hendrawan, Sucahyawati, Cahyandi, Indriyani, \& Lusiani, 2018) mengatakan bahwa berdasar hasil penelitian menunjukan semakin mendekati masa pension pegawai makin tidak produktif dan cenderung asal-asalan.

Undang-undang dan peraturan K3 (Kesehatan dan Keselamatan Kerja) harus dilakasanakan di perusahaan karena sudah menjadi amanat bagi perusahaan untuk melaksanakan dan pemerintah sebagai pengawasnya. Perlindungan pemerintah bagi warganya adalah dengan cara membuat undangundang dan mengawasi pelaksanaannya.

\section{Kesimpulan}

Berdasarkan peneltian bahwa paling banyak pada kategori cukup yaitu 25 orang atau $52,5 \%$ dan paling sedikit pada kategori kurang yaitu 5 orang atau 12,5. Hasil penelitian disebakan sebagain besar responden berpendidikan SLTA dan telah diadakan pelatihan Dasar Kesehatan dan keselamatan kerja yang di dalam terdapat materi tentang Undang dan peraturan keehatan dan keselamatan kerja.

\section{DAFTAR PUSTAKA}

Arikunto. (2010). Metodologi Penelitian. Rineka Cipta.

Artiningsih, N. (2011). Hubungan Antara Tingkat Pengetahuan Dan Sikap Wanita Usia Subur Dengan Pemeriksaan Inspeksi Visual Asam Asetat Dalam Rangka Deteksi Dini Kanker Cerviks. Program Pascasarjana Universitas Sebelas Maret Surakarta.
Chandra, Y. (2009). Gambaran Pengetahuan Wanita Tentang Sadari Sebagai Deteksi Dini Kanker Payudara Di Kelurahan Petisah Tengah Tahun 2009. Fakultas Kedokteran Universitas Sumatera Utara Medan.

Hendrawan, A. (2018). Analisa Keselamatan Dan Kesehatan Kerja Pada Nelayan. Jurnal Saintara, 3(1).

Hendrawan, A. (2019). Analisa Indikator Keselamatan Pelayaran Pada Kapal Niaga Andi. Jurnal Saintara, 3(2).

Hendrawan, A., Sucahyawati, H., Cahyandi, K., Indriyani, \& Lusiani. (2018). Hubungan Pendidikan Dan Organizational Citizenship Behavior (Ocb) Terhadap Indikator Keselamatan Nelayan. Prosiding Seminar Nasional Universitas Pekalongan "Job Outlook Mencari Atribut Ideal Lulusan Perguruan Tinggi, 1-11.

Notoadjmojo. (2010). Prilaku Kesehatan. Rineka Cipta.

Octavia, C. (2009). Gambaran Pengetahuan Ibu Mengenai Pemeriksaan Pap Smear Di Kelurahan Petisah Tengah Tahun 2009. Fakultas Kedokteran Universitas Sumatera Utara Medan 2009.

Puspitasari, F. (2014). Gambaran Tingkat Pengetahuan Dan Sikap Tentang Monitoring Kadar Gula Darah Mandiri Pada Penderita Dm Di Rs $\mathrm{Pku}$ Muhammadiyah Yogyakarta. Program Studi Ilmu Keperawatan Fakultas Kedokteran Dan Ilmu Kesehatan Universitas Muhammadiyah Yoyakarta.

Sani, F. N. (2011). Hubungan Tingkat Pengetahuan Sehat - Sakit Dengan Sikap Mahasiswa Universitas Muhammadiyah Surakarta Tentang Perilaku Hidup Bersih Dan Sehat. Jurnal Kesmadaska, 2(2).

Sariningrum, E. (2009). Hubungan Tingkat Pendidikan, Pengetahuan Dan Sikap Orang Tua Tentang 
Kebersihan Gigi Dan Mulut Pada Anak Balita Usia 3 - 5 Tahun Dengan Tingkat Kejadian Karies Di Paud Jatipurno. Fakutas Ilmu Kesehatan Universitas Muhammadiyah Surakarta.

Soraya, M. N. (2013). Anemia Pada Ibu Hamil Dengan Kepatuhan Dalam Mengkonsumsi Tablet Besi ( Fe ) Di Puskesmas Keling Ii Kabupaten Jepara. Program Studi Pendidikan Dokter Fakultas Kedokteran Dan Ilmu Kesehatan Universitas Islam Negri Syarif Hidayatullah Jakarta.

Syarfa, I. (2015). Gambaran Tingkat Pengetahuan, Perilaku Merokok Dan Nikotin Dependen Mahasiswa Uin Syarif Hidayatullah Jakarta. Program Studi Ilmu Keperawatan Fakultas Kedokteran Dan Ilmu Kesehatan Universitas Islam Negeri Syarif Hidayatullah Jakarta. 